\title{
FOLKLORISTICS ONLINE. THE ESTONIAN EXPERIENCE
}

\section{Mare Kõiva}

Estonians are a small nation on the borderline of middle Europe. Although we eagerly embraced Internet when it first started spreading here outside the circle of computer specialists in 1993, our position online is somewhat different from that of representatives of big nations, especially those speaking the English language as their mother tongue. We own the server with probably the greatest amount of digitised humanitarian science material, but since the majority of material is not in English, a great deal of what we do remains peripheral though our experience is worth distributing.

Already at the beginning of the 1990s, the Internet offered a wide range of scientific material and social research results - web-based books and journals, studies and research journals as well as other materials. The pages, publications and galleries that represented human sciences, appeared in the Internet in the mid-1990s. Folkloristic science as a many-sided discipline is represented in the Internet since the early 1990s and owes much to enthusiastic amateurs. 1995, when the Estonian folkloristic server Haldjas (http:// haldjas.folklore.ee, accessible also as http://www.folklore.ee) was, a wide-scale creating of special editions, text corpora, databases and folkloristic scientific environment began. The server was to satisfy the needs of e-education and gear interest in folklore in representatives of other fields, as well as the generaton oriented to emedia. The server became the largest many-sided folkloristic Internet site, unique also in that its technical side was prepared by folklorists themselves and should thus meet the professional needs of folklorists the best. ${ }^{1}$ In the current article I would like to give an overview of what kinds of electronic publications there are and to point out some of their problematic points, using our experience with folkloristic material.

E-publications have several beneficial features as compared to printed publications: they are relatively cheap and information embedded in them reaches every corner of the world in seconds. If you already have or are planning to establish an academic server 
aimed at presenting material mainly textual in nature, among other things there are questions of target groups and finding their preferences, compiling coherent pages, making use of feedback and direct communication means, the needs of minorities as opposed to the majority and, in Europe, multilingualism to be pondered. The main problem, however, is how to 'take after nature' - how to present the material in all its rich variability. In the case of non-English servers there is also the question of the strategies available for small and big nations to make themselves heard in the flux of information.

\section{SOME BENEFICIAL FACTORS}

E-publications have become an attractive means mainly in connection with the spreading use of Internet: ten years ago the idea to publish online was considered ridiculous while today we regard the Internet as a serious communication medium. In Estonia, one can read all the biggest newspapers online, several journals in Estonia as well as elsewhere are moving in the same direction. In the last couple of years, the guest books of Internet publications have become the almost compulsory "portal-like" commenting features the possibility to give interactive feedback about the material and other people's opinions on this. Such comments have in time become unintended sources and archives of research material that (like special web pages) are studied by folklorists, linguists and ethnologists (e.g. Fialkova \& Jelenevskaya 2001, Kirschenblatt-Kimblett 1996, Schwibbe \& Spieker 1999).

Compared to 1996 when we started, the userdom of folkloristic material has changed and grown. Since then, the number of accesses from both America and Europe, not to mention Asian and African countries, has increased. Many universities and research centres have web archives with their own developmental strategy (see Texas Tech University Uysal-Walker Archive of Turkish Oral Narrative, Indias Folklore library for the scholars of Orissa Indians, many archives of oral history, etc.). ${ }^{2}$

This means that the question of target groups is more and more focal: in which language, in which format and why should this material presented in an e-publication. Also, there are increasingly 
more appeals for more information, so the publisher needs to consider in which form should he keep the material in the Internet and server, how to handle the growing amount of data, and last but not least, what kind and how many search engines are needed to avail easy access to material.

Many consider electronic publishing thinking first of all of the spared printing costs. However, from the point of view of scientific publications, of much more importance is the fact that the Internet allows for creating text compilations or publications consisting of combined different multimedia, offering the reader a new kind of experience. Electronic publishing and search engines allow all of us to use as well as distribute rare material, a development most welcome in the light of the poor equipping of libraries.

\section{DIFFERENT KINDS OF E-PUBLICATIONS}

An academic server dedicated to any one field of science offers an extremely wide choice of possibilities for creating virtual publications. Each of these has its own speciality and circle of users, some of them possible first and foremost or even only in the form of an Internet presentation. The most widely spread form of publication are topical link collections, virtual books, e-books or electronic reprints of published material, e-journals, public databases and chosen text collections, õpikud ja loengumaterjalid, virtual exhibitions and miniportals.

\section{Topical link collections}

There are innumerable pages where someone has collected addresses of sites relating to any one topic. ${ }^{3}$ Often this collection has not been compiled by a scholar of anthropology, ethnology, folklore or mythology, but an amateur trying to give an overview of the pages and texts concerning his or her favourite topics. Such collections either link to everything found on that topic online or, based on some criteria, a selection of pages. ${ }^{4}$ Only in single cases has the hobby become the main field of activity, as in the case of Marshall Brain, author of the pages How Stuff Works, whose treatment of folk calendar issues is surpassable by only single specialists of the 
field. ${ }^{5}$ The majority of institutions and associations try to support official information with a link collection. ${ }^{6}$

\section{Virtual books}

In this case we are dealing with publications created especially for the Internet that have not been published in print. Undoubtedly, they are one of the types of publications most specifically unique to the Internet in Estonia. In most cases, these are big text corpuses or multilingual publications, embedded with numerous (colour) illustrations, video samples and distribution maps. Online, they are much cheaper to edit, the publications are more attractive, material of interest to the reader is easily searchable. In virtual books, visual material is often presented on different levels and through different solutions, also using several channels simultaneously (reading while also listening to foreign or dialect texts, read the notes while listening to the sound sample, watch and listen to a video). ${ }^{7}$

Often, this is also the best way to expose rare manuscripts, religious texts or early publications.

\section{E-books}

To prepare an Internet reprint of previously published material, one needs to scan it and then employ character recognition software. This is best first of all in the case of bulky and rare books. However, we have also employed this in the case of sold-out collections of articles that are in demand but are financially unreasonable to republish. ${ }^{8}$ The main aim here is to offer the reader access to articles and studies otherwise not easily accessible.

In the case of these publications, we have opted for a simple HTMLlanguage. In some cases, however, the printed version carries a certain value in itself. It is most interesting, for example, to browse old bibles one can hardly expect to even see in real life but in picture format in the Internet demand only good bandwidth. ${ }^{9}$

Besides picture format, .pdf (Portable Document Format) has become increasingly popular. ${ }^{10}$ These "portable" documents maintain their original layout no matter what platform or version you use. They are especially helpful in the case of publications with complex 


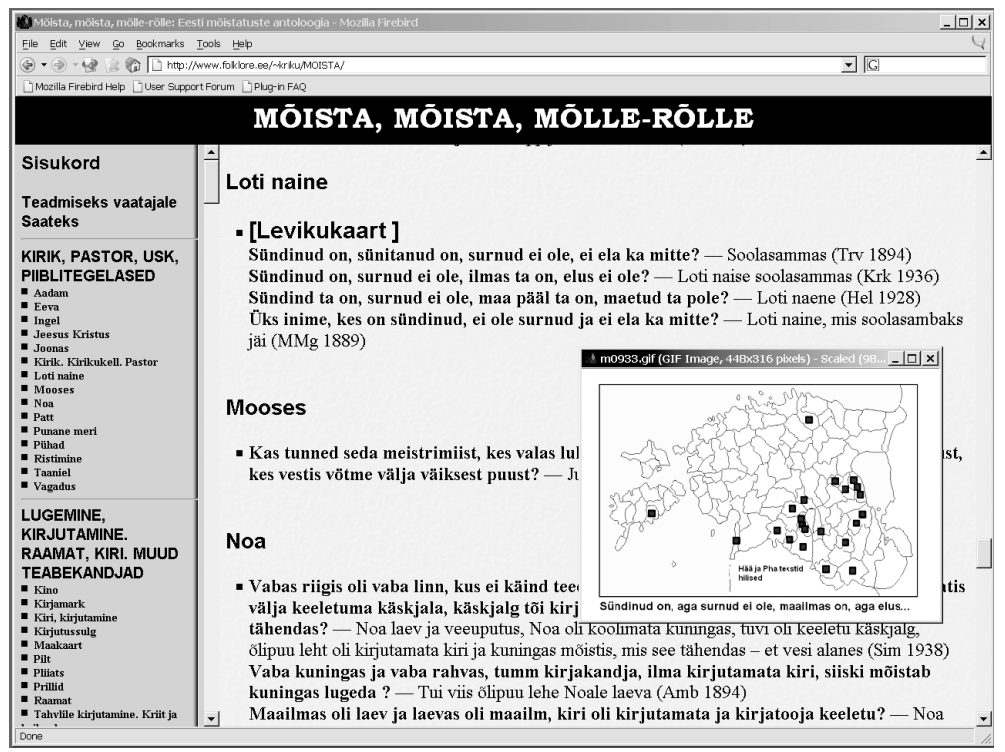

Figure 1. This puzzle anthology, composed and created by Arvo Krikmann, includes more than 600 distribution maps in addition to the puzzle texts. http://www.folklore.ee/ kriku/MOISTA/

layout, e.g. newspapers and journals. Many browsers feature the software needed for reading them as a plug-in, requiring a minimum of user effort in installing.

\section{Public databases and text collections}

In our case, these are authentic, orthographically corrected corpuses of folkloristic material. The texts are indexed either typologically or by some other principle. Depending on the topic under discussion, either the whole corpus is presented on-line or only representatives of the main types with some versions. Such collections also feature some illustrations and as additional material provide distribution maps, etc. ${ }^{11}$

The scope of material is usually in thousands of texts, the text corpuses made up of material previously unpublished that, for various reasons, will probably never be published. Under these we mean 
e.g. distribution maps, first of all so-called "self-filling" maps that are created in answer to the user's request. In most cases such databases are by-products of scientific research or preparative step for further research. The reader can compile this into smaller text collections according to his own needs. Databases also feature the possibility to present material that has been edited to a lesser extent or has not been entirely systematised but which are useful as sources for further research. The newest databases are constituted of folklore gathered from the Internet.

\section{Study materials}

Topical pages offering material prepared for university level lectures ${ }^{12}$ provide the student with the opportunity to obtain in one go all the material related to a course, to find additional material, to acquaint with important theoretical treatments, etc. First it were the representatives of hard sciences that started posting the course materials and tasks. Many lectors, especially in humanities, tend to supply the address of their home page where a number of his or her articles are linked. Such personal articles or even bibliographies are of help in finding interesting literature as well as in checking the accuracy of references. ${ }^{13}$

Materials of folkloristic seminars are mainly intended for a wider range of users than students of any single university. Pages of the narrative and popular religion seminars offer Estonian translations of renowned theoretical articles. ${ }^{14}$ In a way, they supplement for the publications lacking in our libraries. Study materials are, as a rule, created specially for the Internet and are suitable for both printing out and reading on the screen. But this is also internationally employed practice for presenting one's biography, bibliography and also latest research results.

\section{Periodically published reviewed publications}

One of the first Internet projects in Estonian folkloristics were the two hyperjournal, one in English and the other in Estonian. Originally, both were planned to be published on-line only, to save the most on editing and publishing costs, to create a publishing opportunity of some perspective, allowing fast and multifaceted presen- 
tation of research results on Estonians and kindred peoples, to create an information field aimed at several cognitive channels. It is a well-known fact that the deposits of the Estonian Folklore Archives contain, in addition to collected manuscript material also unique films, photos and sound recordings, the majority of which has not and probably never will be published. This was among the reasons for opting for online publishing.

In 1996, our journals were among the very first of humanities publications to publish full texts free online. Undoubtedly the technical level of the journal has been of class - since the very first issue, sound samples were employed (first .au format, since 1997 .mpg2 and .mpg3), and the fourth issue introduced video samples (in .mp format), images of notes, photos, illustrations, etc. The eight issue of Folklore (1998) was the first to be published parallelly as .pdffiles, taking into account the interests of those who wish to read, print and make references to the articles as they are published in print.

Another important point in question was the fact that .pdf format maintains both illustrations and text with special characters in their original look, something hardly achievable with simple HTML. With HTML, the only solution would be to create small images of all the non-standard characters, formulae, Greek phrases, etc. Using Unicode has, in fact, caused many problems with search engines.

This kind of journals have a fairly wide geographical spread and the articles often solicit feedback. Articles published in the journal Folklore have brought both requests for permission to translate and republish. ${ }^{15}$

Many formats were taken into use here as soon as they became available in the Internet. Since the late 1990 s, several important American anthropology journals publish full text in the Internet. However, most journals use only images for additional illustration of material.

6. Virtual exhibitions offer a wide range of information on both written and oral tradition material. In their case, emphasis is on communicating via the aesthetic message. Since many studies of the new media indicate the increased importance of visual and audible 
material for users, its wider use seems inevitable. ${ }^{16}$ Syncretism, the simultaneous blending of traditional music and mental text is typical of folklore and its recording. Thus, virtual exhibitions expand the understanding of tradition.

\section{WHOSE WEB?}

Different kinds of web pages have radically differing userdoms, their age and gender parameters and expectancies divergent. Research conducted by Jonathan P. Bowler (1999) indicates that at the time, $88 \%$ of web museum visitors were from North America, just as ca $59 \%$ of Internet users were from the USA and Canada. ${ }^{17}$ The dominance of North Americans among Internet users has been explained first of all by the fact that information technologies are much more available to them and that their mother tongue is English. Since at least a portion of results and information in the world is attempted to be reflected in English, the English-speaking community has considerably better chances of obtaining information.

We have notices significant changes in our users: with every year they come from a wider geographical area. Also, the time of most accesses has changed: five years ago the "hottest" time was at night (due to the time different with the USA) and during weekend; currently the top is Wednesday and, possibly due to improved school Internet connection, during lesson-time and school season.

The favourites of 25-34-year-olds are electronic books, text archives, translations of rare old texts and their adaptations, commented texts, exhibitions, etc. And 74\% of visitors expect a web page to offer in addition to text also some visual design, preferably a so-called web exhibition, so the text would be illustrated by photos, drawings, animations and sound; they expect interesting multimedia solutions. Even simple "interactivity" is what they seek after. Younger people and those with better computer skills take part in chatrooms, lists, etc. other direct communication channels. Exhibitions that are open parallelly in real life and online - making use of all the possibilities hyperreality offers - are certainly one of the best ways to bring young people to "academic", professional pages. 

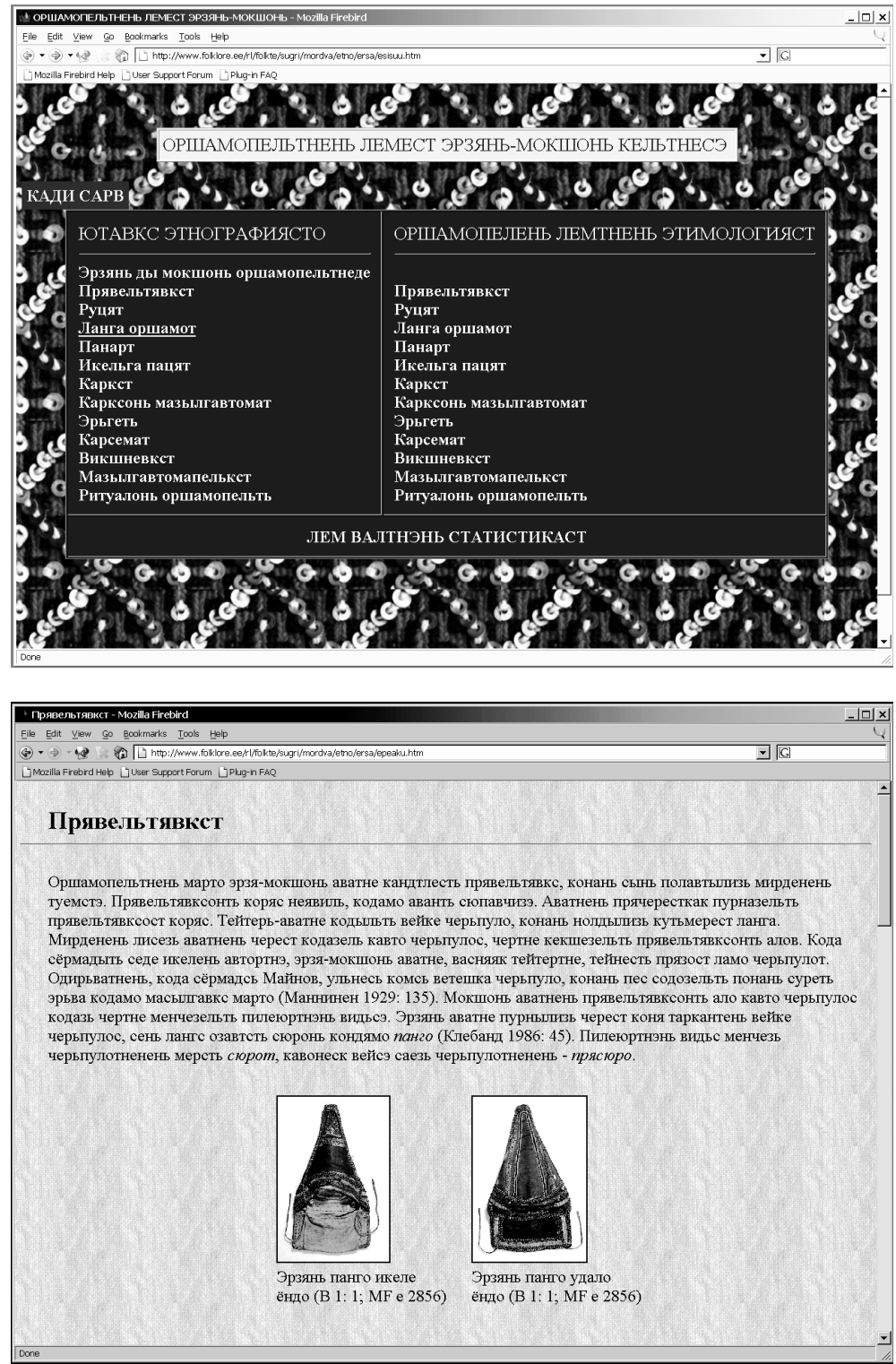

Figures 2-3. The Mordvinian pages include studies and data on their folklore, ethnology and mythology in Estonian, Moksha, Erza and English. The illustrations are courtesy of the Estonian Naturl Museum's collections. http://www.folklore.ee/rl/folkte/sugri/mordval 
All the above point to the fact that the author of an e-publication should have at least some idea of who the readers will be, should try not only to determine who they are but also attempt to widen the circle of users, taking advantage of knowledge about Internet users' preferences. This does not mean that an academic publication should display animated comic strips, blinking buttons or script, ad banners or animations on topics unrelated to their research field. Such means should stay in the domain of commercial web pages, but innovativeness is nevertheless welcome even in periodically published e-publications.

Structuring text is easy: comments can be added to the main text, new topics, elaborations, facts, photos, etc. visual material can be presented on a lower level that the everyday reader might not be interested in but are a thankful addition for those deeply interested in a given topic. Surfing on different linked pages, the reader can find as much information about a topic as he is interested in. I would like to elaborate this in two examples:

In his article in Folklore 11, Väino Poikalainen presents an overview of Lake Onega rock art (Poikalainen 2000). An interested reader finds with this article an overview of rock paintings and a table of the statistical distribution of rock art that can be zoomed into and visualised. First, the reader can move one level down and see what the more famous picture of rock art really look like. ${ }^{18}$ Second, the reader can acquaint with photos of a certain rock art location or see data presented in the article in form of a table or even see a more detailed overview of single locations. At the same time, one more level down, he can find publications on rock art.

Kadi Sarv has compiled a page introducing Mordvinian folk costumes where the front page makes you choose between two alternatives: one subpage offers an ethnographical overview of single pieces of garment by types, of interest for folklorists, ethnographers, design artists, etc. The other introduces etymological vocabulary and statistics of terminology, of interest first of all to linguists. ${ }^{19}$ The main advantage of this kind of layout is that the reader can limit himself with either one of the pages.

Userdom can be widened by embedding a text corpus or e-publication with visual material, web exhibitions, slide-shows or related 
background music. Often, even an uncommented sound sample can give additional information about the tradition, it could give a better understanding of the situation than mere text or photo.

Publications supplying the reader with information about topics interesting to him together with wider information and links to related topics seem to be an effective means of widening the target group. The same result is achieved with co-operation between representatives of different fields, the current mainstream in humanities.

E-publications from different parts of the world nevertheless reveal some regional idiosyncrasies, ${ }^{20}$ in the case of Africa, Samis, NorthAmerican Indians in connection with colour perception. Generally, local idiosyncrasy is hard to attain since often the only result is merely national pathos.

\section{MULTILINGUALISM}

Another means of widening the range of users is creating multilingual publications. Globalisation as all general processes, has its counterforce. In the case of web, this is force is the fast-developing computer networks in mother tongue that are bound to change the general Americanisation and English domination. Practically all nations with their own written language or state develop Internet in their mother tongue. It is the marginal groups and small languages that have quickly taken advantage of the new media ${ }^{21}$ Since information is searched for usually from pages in English, the English language is fast becoming the common language. To some extent, this is similar to the situation in Isaac Asimov's Foundation, where the whole galaxy speaks one and the same language with different dialects. In any case, English has become the lingva franca of science.

If we compare the languages of the world to the world of plants and animals, richness in languages and grammatical forms should be assurance for the culture's good health. In a time of globalisation and disappearing of many languages, it is important to be fluent in and to develop both channels important for mediating information, such as the Internet in the mother tongue and e-publications. This 
also in the case of languages that are rich in oral culture and have only limited written spread, e.g. the Sami language or Vepsian language. ${ }^{22}$ In this case, multilingual publications have several roles ranging from language studies to widening the use of written language.

\section{SMALL AND BIG NATIONS AND THE INTERNET}

Arjun Appadurai (1986) considers the biggest cultural influences in the 20 th century to be migration and media, changing radically people's cultural environment and stereotyped attitudes. In the case of migration, one takes with him or her first of all cultural traditions such as music, narratives, eating habits and important holidays and their celebrating, remembered and continued in the new environment. In many aspects, the Internet is one expression of migration, the seeking and creating of a new environment. This explains why cultural and ethnical minorities expose their ethnical distinguishing features in the Internet more clearly and sharply than big nations, who seem to have no explicit need to do the same.

Globalisation gives a new perspective on the problems of periphery and centre, both concerning science and culture. Seemingly, digital media or the Internet puts all cultures into an equal position, there should be no peripheral regions as information reaches all corners of the world with the same speed. This aspect was especially emphasised in the early stages of Internet philosophy and cyber psychology research. On the other hand, success in communication depends on how much common knowledge the participants share and how similar is their cultural background. In a situation where real contact between different cultures is more and more an everyday occurrence, the area where cultures meet grows and so does the scope of the common information field. All manner of phenomena are increasingly interrelated and also related to similar phenomena in other cultures, leading to the creolisation of cultural phenomena. ${ }^{23}$

This also means that although seemingly everybody speaks "one and the same language" and share a common background system, there is all the more danger of misunderstanding and conflicts (Featherstone \& Robertson \& Lash 1995). Understanding messages 


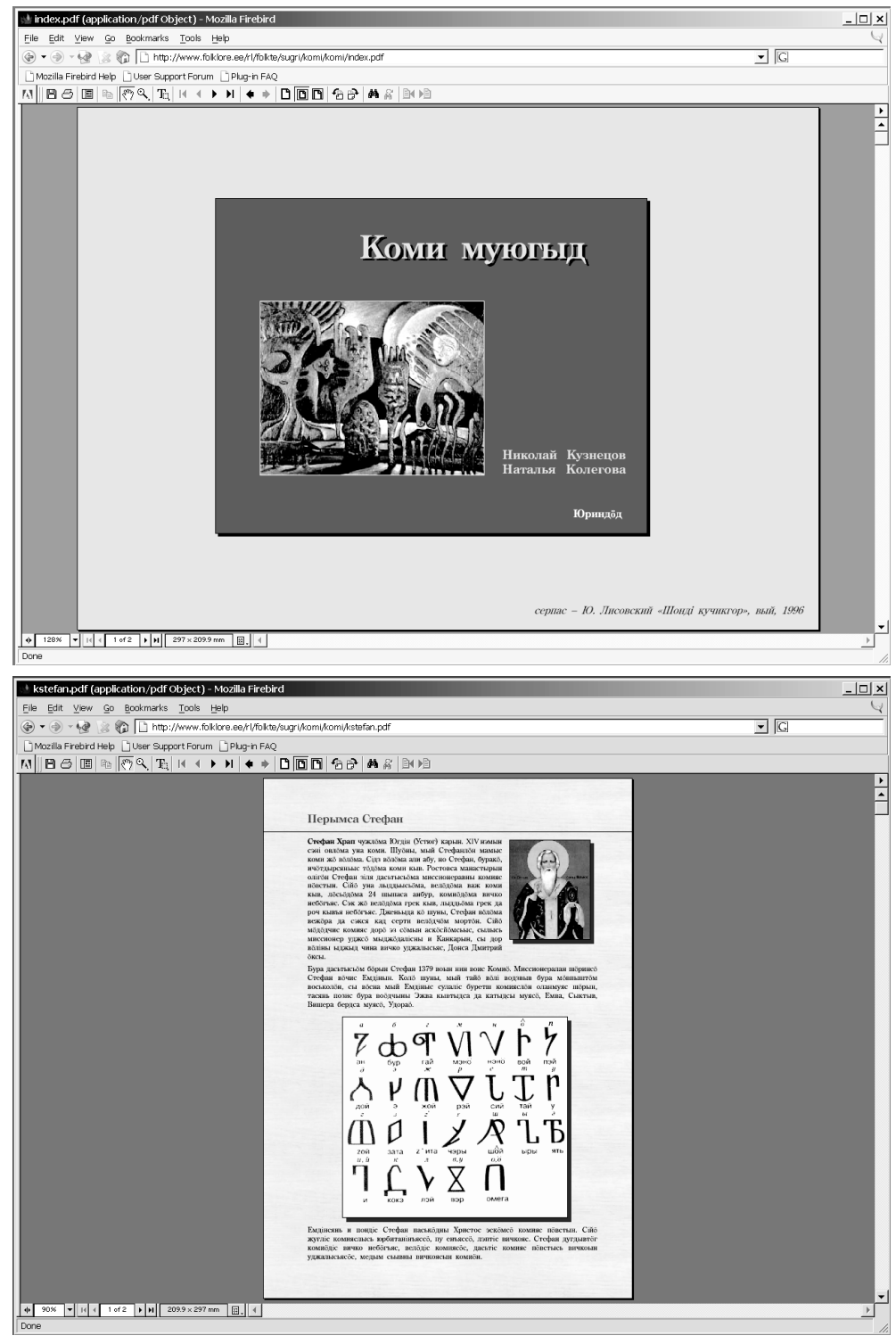

Figures 4-5. The Komi pages feature material in Estonian and Komi languges. Displayed here: the main page and an overview of Stefan of Perm and Komi alphabet. The Komi pages are compiled by N. Kuznetsov and N. Kolegiova.http://www.folklore.ee/rl/folkte/sugri/komi/ 
in as much the same way as possible is facilitated by the activisation of a similar background system, but knowledge about even European cultures is scant. About bigger nations, we have formed some stereotypes, about the small and further away we have no base stereotypes, so we have nothing to compare old information to or to oppose with. In this case, general knowledge and conceptions are often widened to a culture we have no personal experience of. Thus, the cultural phenomena and historical events of a small nation need a careful creation of a background system, tying to its closest language and cultural room, just as single culturemes need to be elaborated upon.

What a small nation does in order to introduce itself, should be multifaceted enough to create a framework for understanding its cultural phenomena, but also to relate new information for the reader or the other party's culture.

In essence, this means presenting the information for two different cultural rooms: the internal and the external. The internal can and must be more thorough and deep than the information intended for the external cultural space that needs to be wider and more superficial, commented to a greater extent and supplied with general cultural markers, as no axioms can be expected to be automatically understandable.

With mediated communication, the media used and its specific features are to be taken into account, this shaping the relayed message's form and means. We once again meet the condition above stated that in the case of a small nation that is relatively less known, much depends on the self-introduction that should ideally take advantage of different visual means, creating a background system partly with the help of emotional memory. All in all, any kind of virtuality should be a visiting card connected with certain ethnical, historical or person-related realities. Visual and auditive material accompanying text helps elaborate and specify the meaning. Most of the web created in connection with the folkloristic project Sugriland ${ }^{24}$ is aimed for many perception channels simultaneously: pictures, video, sound samples and exposed reproductions create one whole with the text, becoming a sample of the culture introduced. Sugriland introduces different small cultures from the Eastern part of Europe and Northern Asia. It mediates both nations 
that have their own researchers and research centres but also those that don't or whose mental culture has for a long time been recorded and analysed in Estonia. The project uses Estonian fieldwork material, abundant archive and private collections that have previously not been exposed to the public. These pages - or rather electronic books that grow as material is added - all have their own face. Some of them are interdisciplinary and compiled by representatives of different fields (in the case of Mordvinian culture, historians, ethnographers, folklorists, linguists, demographers from both Estonia and Mordvinia are involved), intended to give the internal and external a proper balance. Information about different spheres of material and mental culture is presented in Estonian, Erzan, Mokshian and English languages. ${ }^{25}$ The same principle has been used in the case of Komi pages compiled by Nikolai Kuznetsov in Estonian and Komi languages ${ }^{\mathbf{2 6}}$ where, on his choice, in addition to folk culture, an overview of the Komi language and a poetry anthology are presented. Both language samples and poetry can be listened to.

The pages referred so far have been the results of teamwork, but often a good outcome is achieved also by choice of material and vision of a single researcher. The Sugriland culture introductions differ also in that some of them are material presented and chosen by one researcher where quite often thorough academic research has been combined with more emotional and personalised information. This solution features, for example, the Udmurtian web Dzetsh bures' compiled by Aado Lintrop. ${ }^{27}$ Local religion is introduced in two monographs, one of them in .pdf format. A many-sided overview of the history and ethnography of Udmurts is presented together with some lyrical subsections.

Many pages present research results about the rites, religious phenomena or keytopics characteristic of a ethnic group. Thus the Khanty and Mansi pages compiled by Aado Lintrop ${ }^{28}$ feature in addition to other material also interesting articles on the religion of these peoples, especially bear feasts. On the other hand, the web introducing the shamanistic Nganassan culture, introduces some of their famous shamans and their incantations in English. Besides rare sound samples of genuine shamanistic rites, the page also displays some just as rare and beautiful photos. Shamanism is un- 
doubtedly one of the topics today's readers interested in the limits of human perception as well as culture, focus on.

One of the greatest benefits of the Internet is the ease of concentrating material related to a single topic. Several of the pages feature mythology dictionaries of the nation they introduce, these being drafts for a future publication containing invaluable information about the religion of nations that have received too little attention. ${ }^{29}$ Such dictionaries are so far on Votian, Mordvinian and Komi pages; Livonian, Estonian and some others soon to be added. The Sugriland project also plans to unify treatments on folk calendar and interlink music parts. ${ }^{30}$ The results of such long-term undertakings can be evaluated only when some years have passed.

\section{CLOSED AND OPEN TEXT CORPORA, CLOSED AND OPEN STUDIES}

The previous paragraph pointed out the strong and weak sides of web publications that have been heatedly discussed since Internet first appeared and started spreading. E-publications are often in a state of under eternal construction. Unlike printed publications, they are not finished entities, but grow, develop and change depending on the author's will and taste.

There are e-publications that are, by their very nature, open, while others are closed text corpora. A closed corpus or study is in every way similar to a usual publication, it can be cited, the text is finished in every way. ${ }^{31}$ However, open text corpora allow the user to compile a collection of texts and related data that he is interested in at the moment for research, to prepare a lesson or conduct a cultural event.

The Estonian folklorists' server contains numerous electronic books and studies that have open structure. They are, generally, big systematised text corpora that are embedded with search engines, comments and distribution maps. Estonian proverbs ${ }^{32}$ can be listed by their main types, or to choose from among proverbs containing a certain word or expression listed either by density or type. For example, there are 116 proverb types relating to cat, the most popular of them type 6297 "No cat runs into the mouth of a sleeping cat", 
recorded from 230 people. Open text corpora are also Proverb book, ${ }^{33}$ where proverb texts can be listed by topics, as well as the database of saying and phraseologisms. The same can be said about many other big virtual and e-books such as the anthology of Estonian riddles, ${ }^{34}$ the anthology of Estonian animal fairy-tales,${ }^{35}$ the giant legends ${ }^{36}$ ethnographic and ethnologic texts describing life in the 19th and beginning of 20th century, ${ }^{37}$ Estonian folk humour, ${ }^{38}$ the selections of folk songs ${ }^{39}$

In addition to reprints and full text corpora, other big data masses represent the latter type of e-publications. For example, we find a fair number of folk astronomy records in a compilation ${ }^{40}$ where they are systematised by subcategories with the reference of the record added to it.

It seems that almost all classical folklore types are represented in our server. In addition to what is found on the external server, our inner server allows to search and browse texts that have not yet been classified. Only singel types and topics (instrumental music,

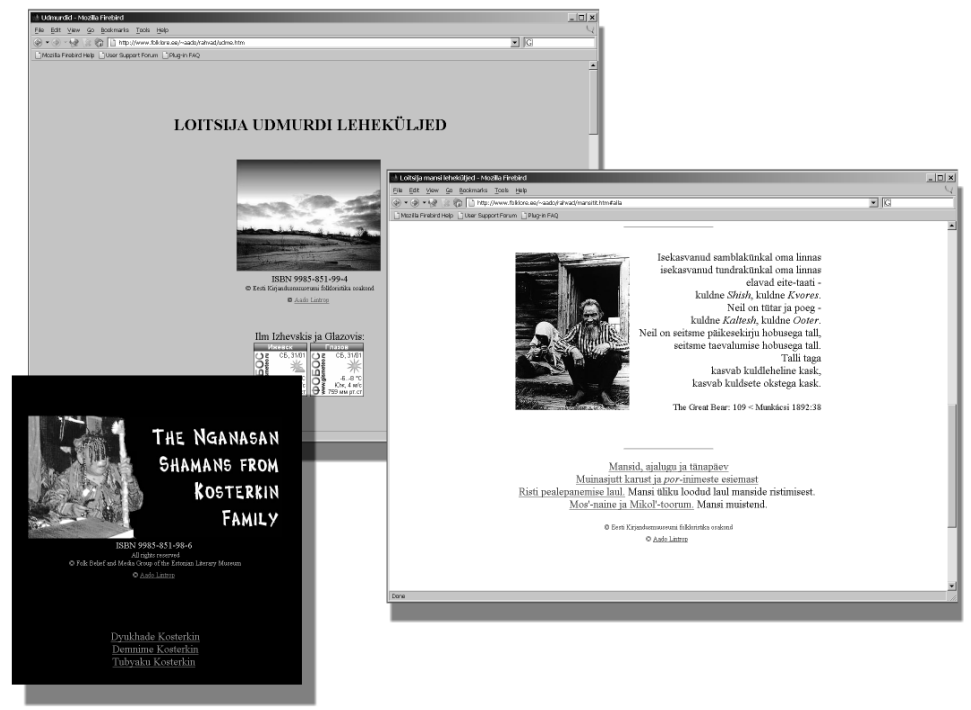

Figure 6. The pages of Finno-Ugric peoples created by Aado Lintrop feature the author's studies as well as his fieldwork material. http://www.folklore.eel aadol 
newer songs, oral heritage narratives, urban legends) are lacking. All this allows the researcher, student, lector to compile his or her own small book of classics according to needs and opportunities. As a counterforce to globalisation, during the past decades, expressions of locality, local history and folklore concerning a specific place or social group have been researched more than previously. Another big advantage is that in the classroom, teachers can use the local area for example by means of the rich narrative and song material collected there in the 19th century, they need not be limited by the little that pupils hear from their parents today.

A separate question is how to attract the reader to return to a page he or she has visited when new information has been added. Of course, here are helpful registration pages that send out news about changes and additions to the registered. The reader is lured partly with information sent to lists. However, readers still seem to use epublications like books - only once. Only favourite books and knowhow are reread sometimes.

The authorship of text and the freedom of the reader in handling the text are also topics that have inspired lengthy discussions. It is claimed that in the case of Internet texts, the reader may not only misunderstand due to his little knowledge but also more freedom to subjectively interpreting the message. There is just as much opportunity for distancing in the case of regular printer text but since digital screen script is much more easily changed it is also easier to create and maintain or delete and change. Therefore the reader perceives the text's content less as "reality as defined by the author" and treats it rather as a collection of signs found in the computer network, thus becoming more and more the author himself(Poster 1994: 191).

\section{COHERENT PAGES - OPPORTUNITIES FOR DEVELOPING THE SERVER}

Many phenomena and texts within a single culture are contradictory, representing different styles and opinions. An academic server could, ideally, to some extent imitate "wild nature" - besides the clearly structured and authorised compilations and books, there 
should also be enough free and chaotic data the reader can navigate on his own.

One of the unarguably greatest advantages of Internet are coherent data and articles that require the author to have exceptionally good overview of the material, a vision of what he intends to achieve and patience in finding and preparing suitable additional material. Such articles represent to some extent the same "wild nature", though as seen by the author. We earlier referred to V. Poikalainen's article on rock art that uses resources in a single server. The other possibility is to connect articles and data related to one topic but located in different servers or parts of the world. This way, many more connections are established, influenced to a smaller or greater extent by the original material and its meaning, but in any case giving it a wider perspective. A phenomenon's cultural uniqueness and individuality becomes visible.

It is clear that numerous integrated articles that emphasise different aspects of material guarantee the representation of both the individual and the general. One such article in our server is about Hugo Raudsaar, ${ }^{41}$ an astronomer who decades ago built his own observatory and a unique proportional model of the solar system in his home farm. The additional material in subsections of the article gives an overview of $\mathrm{H}$. Raudsaar's scientific works, comets, observatories and models of the solar system made by amateurs in Estonia and worldwide, the solar system itself, the unique optical devices in the Tartu Old Observatory, the e-journal Vaatleja ('Observer')and texts in numerous topical galleries. And if you are eager enough to explore further from there, you can end up reading about the science fiction association or the home pages of astronomers.

A remarkable amount of the material in that article is physically situated in a different, academic astronomy server and is totally independent from the author's text. Browsing the subsections and links exposes one of the best-known Estonian astronomers and his daily work, his astronomy-related hobbies. The article has also taken use of different means of visualisation. This overview is achieved by way of slide shows, photos, drawings, videos, etc. It is true that the creator of such articles can rely mostly on academic servers only as their structure and data are stable, constantly safe-copied, 


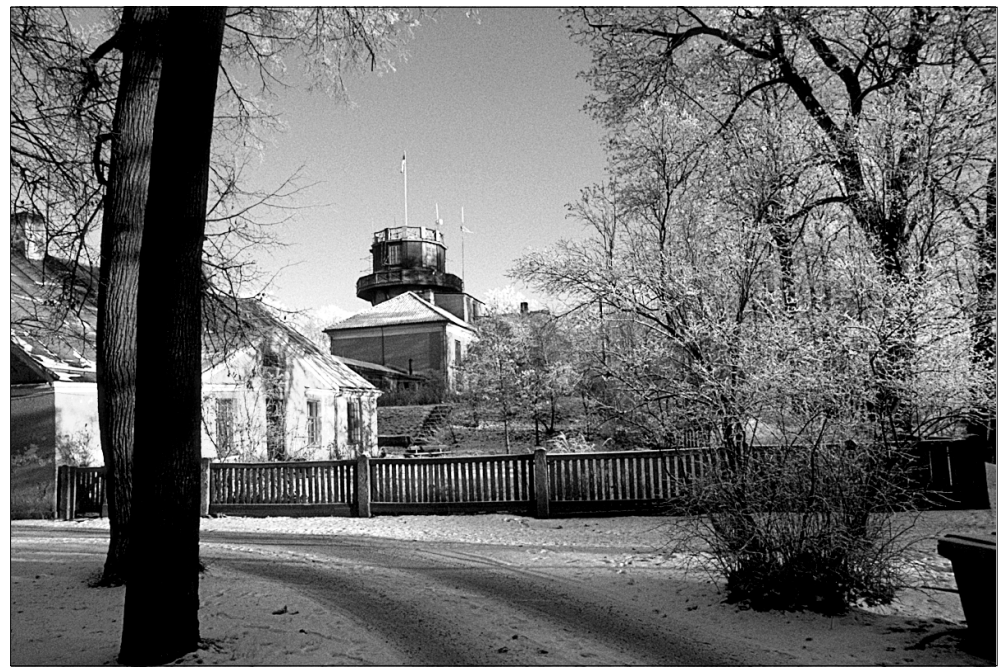

Figure 7. The old Tartu observatory and its server are situated on Toome Hill in Tartu, quite some distance from the folklorists's server. Their pages are linked into a coherent system.

the owner does not throw out the user and his data nor change the link addresses. It is the short life-span of links that very much restricts the wider use of inter-server resources and forces the user to save interesting material onto his personal computer.

We believe that in the course of further development of the Internet, research and publishing based on material in different servers becomes increasingly common, the author's vision in uniting material dispersed in the Internet becoming more important.

\section{FUTURE TRENDS?}

What, then is the position of a small language and small nation in the era of the Internet? Complex. There is little interest in small European nations that are expected to represent the average common Europe. Estonians themselves do use Internet more and more and even the diasporas has become used to finding information about former homeland via the Internet. In the case of material in English, material or treatments of interest are quickly found, as shown 
by letters and enquiries reaching the journal Folklore. The language problem is nothing unique as in a sense everything not in English is peripheral. It only seems that anybody could publish in whichever language; reality dictates otherwise. As a rule, the geographical-cultural principle - to choose the languages of the closest neighbour with a shared common cultural space and/or history and who are therefore interested in objective information (e.g. Lithuania-Poland-Germany; Estonia-Finland; Estonia-Latvia) - does not work. The choice of languages of the world also could depend on the region and earlier cultural contacts, but this does not work either. Out of the big written languages, unerringly English is chosen, there is less material in German and of Russian-French-Spanish-ItalianJapanese-Chinese. In many languages, Internet develops very fast, and for example the Russian is visibly making efforts to become a media language.

According to Internet studies it seems that in the near future there could be some kind of break-through since Internet phenomena in mother tongues has sparkled some interest in researchers. ${ }^{42}$ This new data could make people rethink previous attitudes and shift interest from the English-speaking America. This could lead to the transforming and breaking up of the English-speaking domain. However, it is much more easier (and thus also cheaper) to find someone to translate your material into English or German than into Lithuanian or Polish.

There are increasingly more joint pages that were expected since the mid-1990s. This means that you can find all the necessary information about a geographical or cultural region or domain from a single page. How its subsections are designed, depends on the authors. ${ }^{43}$

Portals have won great popularity, offering different information in great quantities. The main deficit in a portal has been considered that its messages are short. Principally there nothing to restrict using it also a gateway to longer texts and data masses. This is one of the road Internet development could take, among other things because in addition to static computer-mediated communication it makes use of different possibilities for direct communication, ranging from expressing one's opinion and commenting to chatrooms and real-time forums. 
However, striving for variety and scope, portal and direct communication are unavoidable. This is also what an open text corpus requires, in the ideal allowing direct communication with the user and even incorporation of material added by the user. For long time it was, indeed, believed that the unique characteristic of electronic media is the growth of individual motivation and creativity, first of all due to the opportunity to make your own choices and the interfere, to create new texts.

Simplification of multimedia means has made them available to the everyday user, making the relations of official and individual information more complex than ever. Technical simplification has highlighted the questions and ethics of direct interference and centralised information. The reactions of a free forum reflect the problems and problematic areas in the real society. Every virtual community of more or less stable membership follows the moral rules and behavioural norms applicable in the real society and is not at all freed from all and any kind of rules on language usage and expression styles. Otherwise, their social status would suffer.

The more experienced the user, the more he can find and put to good use. The majority of databases and big text corpora offer the opportunity to compile studies but also practical applications: to make your own collection of texts according to some freely chosen criteria. Schools can used this to compile textbooks on local heritage, copying their selection, instead of turning it into a new separate publication.

It is first of all the skills of teachers, their wish and courage to use the computer that are not proportional to what is available today. Often also the skills of humanities students leave much to wish for.

One of the main problems with serial publications and academic text corpora is stable financing. Already at the beginning of the 1990 s, many web analysts stated that without capital investments or maintaining a server with little capacity is not perspective. Any kind of digitalisation and analysing of big text corpora is a timeconsuming work that requires technical equipment, software creation or licence, with publications come costs for artistic design, etc. Applying for financial support from different foundations project- 
by-project makes continuity difficult since long-term, wide-scope projects and periodical publications are not favoured.

Considering all this, a virtual strategy, thinking through what and to whom you want to offer and how this fits in the current cultural context, must not be ignored. Is the only intention to be an archive or library, is the only function online to give a sign that you exist or to be also a mediator of science, an active source of information or even the director of culture and science. Is the aim a monologue or is there readiness for a dialogue in virtual reality.

\section{Comments}

1 The first administrator of the Haldjas network, Sander Vesik, was the main idea generator and applier in the planning of LAN and web for folklorists in 1995. Next year, large-scale web enhancement was begun. Th general design and many technical innovations originted from Andres Kuperjanov, who became the second editor of two electronic journals. Many thorough e-publications and web pages were created by folklorists Arvo Krikmann and Aado Lintrop. The web page for the chair of folkloristics at Tartu University was created by Risto Järv.

${ }^{2}$ For example, Uysal-Walker. Archive of Turkish Oral Narrative http:// swco.ttu.edu/aton_html/index.htm, at the Texas Tech University; Adibasi Sanskruti Gabesana Parishad (ASGP): Folklore library for the scholars of Orissa, India www.asgporissa.org, founded in 1985 by a group of indigenous leaders and academicians on folklore research in Sinapali, located in Nuapada district, it has grown up to a rich depository of folklore resources. These are single examples from the plothora of similar pages.

${ }^{3}$ I hereby purposedly leave out of consideration web catalogues compiled by search portals.

${ }^{4}$ One good example of a web site (http://www.pibburns.com/mythfolk.htm) compiled by an amateur is by Philip R. "Pib" Burns, a computer scientist, promoter of OS2 and several folkloristic topics.

${ }^{5}$ See for example http://howstuffworks.lycos.com/christmas.htm

${ }^{6}$ The Congress Library ethnology page, for example, presents a link collection overview of all institutions as well as publications active in the field. Today, the same is offered by the home page of the American Folklore Society http://afsnet.org/. 
${ }^{7}$ See for example the so-called Sugriland project: the majority of pages is made up of multilingual research results. For example, Mordvinian ethnology and religion (http://haldjas.folklore.ee/rl/folkte/sugri/mordva/ index.html) consists of pages in Estonian, Erzan, Mokshan and some parts in English. While Mordvinian pages are rich in original photos, graphs, original works of art, then Nganassan pages offer also sound samples (http://haldjas.folklore.ee/ aado/ngin.htm), the Khanty and Udmurtian pages also contain video samples (http://www.folklore.ee/rl/folkte/sugri/hant/ index.html; http://haldjas.folklore.ee/ aado/rahvad/udme.htm).

${ }^{8}$ For example: Sator I (http://haldjas.folklore.ee/rl/pubte/ee/sator/); the Vestring dictionary of the Estonian language from the 18th century (http:/ /haldjas.folklore.ee/ kriku/VESTRING/index.htm), also F. J. Wiedemann' 1876 publication Aus dem inneren und äusseren Leben der Ehsten http:// haldjas.folklore.ee/rl/pubte/ee/vanad/aiale/

${ }^{9}$ See the rare Göttingen Guttenberg bible http://www.gutenbergdigital.de/

${ }^{10}$ Read more on the producer's page: http://www.adobe.com/products/acrobat/readstep.html

${ }^{11}$ Database of sayings and phraseology (http://haldjas.folklore.ee/rl/date/ robotid/leht3.html) and folk astronomy http://haldjas.folklore.ee/ aado/ maailm/, a representative anthology of Estonian riddles with more than 600 distribution maps, written by A. Krikmann http://haldjas.folklore.ee/ \%7Ekriku/MOISTA/).

${ }^{12}$ For example, A. Krikmann's humour sites http://haldjas.folklore.ee/ $\sim \mathrm{kriku} /$ HUUMOR/nljtypol.htm and lectures on short forms http:// haldjas.folklore.ee/ kriku/ALLIK/index.htm, T. Jaago's pages on family heritage http://haldjas.folklore.ee/rl/folkte/pere/pere.htm.

${ }^{13}$ See W. Labov's home page http://www.ling.upenn.edu/ labov/home.html; D. Ben Amos http://www.sas.upenn.edu/folklore/faculty/dbamos/

${ }^{14}$ The seminar is held weekly, introducing treatments of different theoretists or experiments with applying theory to Estonian material. http:// haldjas.folklore.ee/seminar/

15 The Finnish Elore is older than Folklore but has remained a text-only publication, mostly in Finnish and Swedish http://cc.joensuu.fi/ loristi. Today, for example, also avaiable via the Internet are the FF Network newsletter http://www.folklorefellows.org/ and, represented by at least pages introducing their contents, such journals as Marvels and Tales. Summaries in English and older volumes have been latelt internetized by many national magazines, e.g. in Lithuania http://www.lfcc.lt/ 
${ }^{16} \mathrm{http} / /$ haldjas.folklore.ee/rl/pubte/ee/galerii/kenia00/

17 Internet Industry Almanac 1998. In 2001, 35\% of the Estonian population were computer users, the number of home computers has soared.

$18 \mathrm{http}: / /$ haldjas.folklore.ee/folklore/vol11/pics/pfig3.htm; http:// haldjas.folklore.ee/folklore/vol11/pics/pf3_13.htm

${ }^{19} \mathrm{http} / / /$ haldjas.folklore.ee/rl/folkte/sugri/mordva/etno/sisukord.htm - the same in Erzan can be found at http://haldjas.folklore.ee/rl/folkte/sugri/ mordva/etno/ersa/esisuu.htm

${ }^{20}$ The Internet is subject to as fast changes in fashion as real life. Colours and technical solutions (frames, stylsheets, etc.) that a couple of years ago were innovative are today yesterday's fashion or everyday means. As to colours, the currently popular light blue and pastel shades were an abrubt change of course after the black pages with green and red buttons and text dominant some years ago. So that when a couple of years ago owners of a non-black web page were considered "greenhorns and outdated", today users of this same style would be dubbed the same.

${ }^{21}$ See e.g. the article on shamanism in the Internet by Aado Lintrop in Media, Folklore, Mythology (Tartu 2002, ed. by Mare Kõiva).

${ }^{22}$ Resources on Sami language and culture can be found in Swedish, Norgewian, Finnish as well as American web space; the recently established St. Petersburg Vepsian Society web page narod.kodima.ru presents newspapers in Vepsian, poetry, etc., as well as translations into Russian and English.

${ }^{23}$ Ulf Hannerz highlighted creolisation processes in several of his researches. Transnational Connections: Culture, People, Places. New York: Routledge. 1996.

${ }^{24}$ Sugriland - in Estonian 'Sugrimaa' derived from the Estonian slang expression sugri, sugri-mugri. Sugri is an abbreviation referring to FinnoUgric peoples and languages, sugri-mugri is a simple language game. Both terms have a friendly evaluative subtone.

${ }^{25}$ Mordvinian ethnology, folklore and religion can be found at http:// haldjas.folklore.ee/rl/folkte/sugri/mordva/index.html.

${ }^{26} \mathrm{Komi}$ world is at http://haldjas.folklore.ee/rl/folkte/sugri/komi/index.html. The Komi version of the text is edited by Natalja Kolegova. Belief overviews are written by Komi researchers and Nikolai Kuznetsov. 
${ }^{27}$ See http://haldjas.folklore.ee/ aado/rahvad/udme.htm

${ }^{28}$ Khanty web is at http://haldjas.folklore.ee/rl/folkte/sugri/hant/index.html ; Mansi web http://haldjas.folklore.ee/ aado/rahvad/mansitit.htm ; see also A. Lintrop "Palakesi obiugri mütoloogiast" I-IV, Mäetagused nr. 4-7 and A. Lintrop "Khanty Bear Feast Songs Collected by Wolfgang Steinitz". Folklore, vol. 6. Nganassan pages are at http://haldjas.folklore.ee/ aado/ ngin.htm.

${ }^{29}$ The first part of the Votian dictionary see http://haldjas.folklore.ee/rl/ folkte/sugri/vadja, compiled by Madis Arukask and Ergo-Hart Västrik; Erzan-Mokshan mythology dictionary is compiled by Tatjana Devjakina, who has also translated the dictionary into Mokshan: see http:// haldjas.folklore.ee/rl/folkte/mordva; Komi mythology is written by Irina Iljina, Nikolai Konakov, Oleg Uljashev, Valeri Sharapov, translation into Estonian and Komi languages Nikolai Kuznetsov. Livonian folk belief is thoroughly overviewed by Oskar Loorits in Liivi rahva usund I-V, published electronically at http://haldjas.folklore.ee/rl/folkte/lru. Interesting Estonian material is e.g. Ülo Tedre's weddign dictionary, published in Mäetagused. Such a congolomerate dictionary of folk belief and mythology resembles Encyclopedia Mythica http://www.pantheon.org/mythica.html, Wikipedia, The Free Encyclopedia http://en.wikipedia.org, God-u-like: An Irreverent Look at the Faith Industry http://www.godulike.co.uk/

${ }^{30}$ Mordvinian folk calendar overview by Mall Hiiemäe http://www.folklore.ee/ $\mathrm{rl} /$ folkte/sugri/mordva/rk/, Estonian folk calendar is quite thoroughly featured by the educational www.Miksike.ee and personal web pages.

${ }^{31}$ Among these are most all monogaphs and article collections, but also the majority of Sugriland pages are not meant to be freely reorganised. The author that has received an ISBN number for a publication can not change the manuscript or article according to his or her will any longer, but needs to publish a second, improved version. Authorship in Internet publications is similar to printed ones.

${ }^{32}$ Compiled by A. Hussar, Arvo Krikmann, Ingrid Sarv, Rein Saukas, in the Internet http://haldjas.folklore.ee/rl/date/robotid/leht1.html.

${ }^{33}$ Proverb book Vanasõnaraamat http://haldjas.folklore.ee/ kriku/VSR/ FRAMEST.HTM is an e-version of the academic proverb publication of the same name from 1984, compiled by Anne Hussar, Arvo Krikmann and Ingrid Sarv. The database of phraseologisms http://haldjas.folklore.ee/rl/ date/robotid/leht3.html search engine features ca 25,400 texts from the 1993 publication Dictionary of fraseology 'Fraseoloogiasõnaraamat' by Asta Õim as well as the EFA folklore archives and the Institute of Estonian 
Languages dialect archive. Material relating to proverbs, phraseologisms and riddles has been Internetised by Arvo Krikmann.

${ }^{34}$ A. Hussar, Arvo Krikmann, Rein Saukas and Piret Voolaid Mõista, mõista, mõlle-rõlle http://haldjas.folklore.ee/ kriku/MOISTA

${ }^{35}$ P. Kippar Animals, Birds, Insects. Estonian Animal tales. 'Loomad, linnud, putukad. Eesti loomamuinasjutud' is a continuation of the fairytale catalogue published in FFC series, a commented collection of texts available in Estonian (http://haldjas.folklore.ee/rl/pubte/ee/muina/loomad/ index.html) and German (http://haldjas.folklore.ee/rls/tiere/).

${ }^{36}$ Giant legends are in the Internet at (http://haldjas.folklore.ee/rl/folkte/ myte/kalev/index.html ; http://haldjas.folklore.ee/rl/folkte/myte/pagan/ index.html; http://haldjas.folklore.ee/rl/folkte/myte/olev/index.html).

${ }^{37}$ O. Loorits Former Estonian Life Style 'Endis-Eesti elu-olu' see http:// haldjas.folklore.ee/rl/pubte/ee/eluolu/elu1/

${ }^{38}$ R. Põldmäe Estonian Folk Humor 'Eesti rahvanaljandid' http://haldjas. folklore.ee/rl/pubte/ee/nali; Soviet Time Humor from Tartu 'Nõukogudeaegseid nalju Tartust' http://haldjas.folklore.ee/ kriku/HUUMOR/ soviet.htm The newest database of Internet jokes, created by Liisi Laineste: http://www. folklore.ee/ liisi/raamid.htm .

${ }^{39}$ Estonian Folk Songs. Anthology. Compiled by Aino Koemets, Ruth Mirov, Udo Mägi, Veera Pino, Ülo Tedre. Thanks to Paul Hagu, the volumes of archaic South-East runo songs collected by Jakob Hurt are easily accessible at http://haldjas.folklore.ee/rl/pubte/setu/laul. Eda-Kai Simmermann's project brings to the reader a number of old songs together with notes and sound samples see Lõuna-Eesti Väike Kannel http://haldjas.folklore.ee/ Kannel/

${ }^{40}$ Aado Lintrop. Maailm, taevas ja taevakehad http://haldjas.folklore.ee/ aado/maailm

${ }^{41}$ See Andres Kuperjanov.Täheonu. Mäetagused nr 7.http://haldjas.folklore.ee/ tagused/nr7/index.html

${ }^{42}$ Browsing treatments of virtual reality leaves the impression that more and more attention is paid to national sites; the same trend is observable in general theoretical approach.

${ }^{43}$ See e.g. http://www.nativeculture.com/lisamitten/indians.html; Art Musem Network http://www.amn.org/ 


\section{References}

Appadurai Arjun 1986. Center and periphery in anthropological theory. Comparative Studies in Society and History 28 (2), 356-361.

Appadurai, Arjun 1990. Global Cultural Flow. Disjuncture and Difference in the Global Cultural Economy. Public Culture 2: 2, pp. 3-15.

Barbara Kirshenblatt-Gimblett 1996. The Electronic Vernacular. Marcus, George E. (ed.). Connected: enagements with media. Late Editions, 3. Chicago: University of Chicago Press, 1996. http://www.nyu.edu/classes/ bkg/issues/electronic-bkg.htm

Bowen, Jonathan P. 1999. Time for Renovations: A Survey of Museum Web Sites. http://www.museums.reading.ac.uk/mw97/paper/

Featherstone, Mike \& Robertson, Roland \& Lash, Scott. Global Modernities. Sage Publications 1995.

Fialkova, Larisa \& Yelenevskaya, Maria 2001. Ghosts in the Cyberworld: An Analysis of Folklore Sites on the Internet. Fabula, 1-2, pp. 6468.

Hannerz, Ulf 1996. Transnational Connections: Culture, People, Places. New York: Routledge.

Lal, Vinay. 1999. The Politics of History on the Internet: CyberDiasporic Hinduism and the North American Hindu Diaspora. Diaspora: A Journalof TransnationalStudies 8, pp. 136-172.

Poikalainen, Väino 2000. Some Statistics of Rock Carvings at lake Onega. Folklore. An electronic Journal of Folklore, Vol. 11, pp. 60-69. http:// haldjas.folklore.ee/folklore/vol11/carvings.htm

Poster, M. 1994. The Mode of Information and Postmodernity. Crowley, D. \& Mitchell, D. (eds.) Communication Theory Today. Cambridge: Polity Press.

Schwibbe, Gudrun \& Spieker, Ira 1999. Virtuelle Friedhöfe. Zeitschrift für Volkskunde 95: 2, pp. 220-245. 